\title{
Women, Work \& Welfare: Globalisation, Labour Market Reform and the Rhetoric of Choice
}

\author{
by \\ Angela Barns \& Alison Preston \\ Women's Economic Policy Analysis Unit \\ Curtin University of Technology \\ Discussion Paper Number 23 \\ August 2002 \\ Women's Economic Policy Analysis Unit (WEPAU), \\ Curtin Business School, Curtin University of Technology \\ GPO Box U1987, Perth 6845. \\ http://www.cbs.curtin.edu/research/wepau/
}




\section{INTRODUCTION}

Australia's social, economic and political order continues to undergo fundamental change. Since the 1980s, the benefits of globalisation and associated micro-economic reforms have dominated the public agenda and continue to generate contentious debate ${ }^{1}$. In particular, the deregulation of Australia's product and labour markets, alongside the increased emphasis on competition and the dismantling of the welfare state are subject to critical analysis. Within the labour market the increasing wage and income inequality, the growth in relative poverty, the increased use of flexible employment contracts (part-time, temporary, casual and self-employment) and the persistently high levels of unemployment have been noted as particularly alarming ${ }^{2}$. Concerns have also been raised in relation to the restrictions placed upon people's access to governmentprovided income support through social security, particularly within a labour market characterised by job insecurity and irregular income ${ }^{3}$. Whilst such changes have had profound implications for both women and men, this paper argues that the patriarchal context within which globalisation, labour market deregulation and welfare reforms occur, exacerbates the economic, social and political vulnerability of many women. Given this predicament, the case for further deregulation of the labour market is far from compelling, in fact from a feminist perspective, the argument in favour of competitive labour markets is virtually non-existent.

Using feminist economic and social framings, this paper explores the consequences of deregulation as they effect women's participation in the Australian labour market and the parallel relationship with women's access to social security. Beginning with a brief overview of globalisation and the underpinning theory of neo-classical economics, the paper also highlights key legislative developments in and processes labour market restructuring and offers some empirical evidence on the detrimental effects of these reforms. This latter issue is illustrated through a critical examination of women's experiences of inequality, labour standards, bargaining power, job quality, unemployment and access to income support.

\footnotetext{
${ }^{1}$ Wiseman John Global Nation: Australia and the Politics of Globalisation 1998; Capling Ann Considine Mark and Crozier Michael Australian Politics in the Global Era Addison Wesley Longman Melbourne 1998.

${ }^{2}$ Mitchell Deborah 'The sustainability of the welfare state: debates, myths, agendas'1997 Just Policy $9 \mathrm{p}$ 53; Rees Stuart 'Economic rationalism: An ideology of exclusion' 1994 Australian Journal of Social Issues 292 p 171; Pocock Barbara 'All change, still gendered: The Australian labour market in the 1990s' The Journal of Industrial Relations 404580.

${ }^{3}$ Fincher Ruth and Saunders Peter 'The complex contexts of Australian inequality' 2001 Creating Unequal Futures: Rethinking Poverty, Inequality and Disadvantage Allen \& Unwin St. Leonards p 1.
} 


\section{GLOBALISATION AND ECONOMIC THEORY}

In definitive terms, globalisation refers to the integration of national economies through the 'free' flow of goods and resources, such as trade, capital and labour. Since the global economic upswing of the 1990s, governments, business and industry have promoted globalisation as an inevitable consequence of capitalist progress; spurred on by the rapid expansion in information technologies, trade liberalisation and trade agreements and transnational companies. Within the Australian context, the current Howard Government promotes globalisation from within a deterministic discourse, justifying the implementation of radical economic and social policy reform as in keeping with the evolutionary process of modernisation;

Globalisation is with us and will be with us forever and people who imagine that somehow or other we can hold back the tide of globalisation don't understand the modern world ${ }^{4}$.

Globalisation is premised on the neoclassical belief that trade is the key to generating financial sustainability for all society. The basis for this contemporary trade theory can be traced to David Ricardo who, in the early nineteenth century, advocated the principle of comparative advantage through specialisation. Although various institutions, such as the General Agreement on Tariffs and Trade (GATT), established in the wake of the second world war, were developed to advance this principle, it wasn't until the late 1980s and early 1990s, with the adoption of new information technologies and greater public acceptance of conservative political arguments, that globalisation became a taken-for-granted reality.

In Australia, as with many other western capitalist economies, trade liberalisation and the accompanying liberalisation of financial and product markets, brought with it calls to deregulate the labour market. The necessity of both forms of deregulation was argued upon a platform of mutuality; one reform could not be done without the other. Proponents of such restructuring argued that without labour market reform, employers would be competing in a global market with 'one arm tied behind their back' ${ }^{5}$. In Australia these arguments garnered even more support given

\footnotetext{
${ }^{4}$ Gordon Michael and Henderson Ian ‘Sun's out, make hay, Howard says', The Australian 18 July 1997.

5 Singleton Gwynneth 'Introduction: Howard's way', Gwynneth Singleton Ed The Howard Government: Australian Commonwealth Administration 1996-1998 University of New South Wales Press Sydney 2000a.
} 
that the highly institutionalised system of award and wage determination had been predicated on a protectionist set of trade arrangements. ${ }^{6}$

However, the calls for reform did not halt at the labour market. Parallel reforms were considered to be well over-due in relation to Australia's taxation and welfare systems. In particular, neoclassical economists argued that high marginal tax rates acted as a disincentive on the supply of additional labour and effort ${ }^{7}$. Similarly, income support for low-income workers and the unemployed hindered the operation of a 'free and competitive' labour market ${ }^{8}$.

Underpinning these reform agendas was the Chicago school economists' resurrection of classical economic theory. Over the course of the late 1950s and 1960s these economists harnessed mathematics, econometrics and model building to develop a highly influential theory of supply side economics ${ }^{9}$. A theory which in the twenty-first century continues to dominate the economic, social and political agendas of the majority of capitalist countries. Integral to neoclassical economics is the assumption that people are rational, they think at the margin, and respond to incentives. Neo-classical economic theory similarly believes that the decentralised decisions of firms and households makes for an efficient allocation of resources and that, within a decentralised market economy, prices are the 'invisible hand' directing economic activity. It is only when 'institutions', such as governments, unions and employer organisations intervene that prices (i.e. wage - the price of labour) are prevented from adjusting naturally. This in turn affects the invisible hand's ability to allocate resources thus, generating inefficiency. In the case of the labour market such inefficiency causes markets to fail which translates into involuntary unemployment.

Although neoclassical economic theory is predicated on a simplistic set of assumptions it is, as indicated above, a highly influential and powerful economic framework. Many governments have rigidly subscribed to its teachings as is reflected in their policy agendas;

\footnotetext{
${ }^{6}$ At the turn of the last century, under the banner of New Protection, firms deemed to be paying 'fair and reasonable wages' were to be exempt from paying excise tax. The Harvester Judgement of 1907, which set the path of Australian wage determination for the remainder of the Century, was a test case on what was meant by 'fair and reasonable wages'. Plowman David 'Protecting the low income earner: Minimum wage determination in Australia' 1995 Economics and Labour relations Review 62 p 252.

${ }^{7}$ Quiggan John 'The public sector as a job engine' 2000 S Bell Ed The Unemployment Crisis in Australia: Which Way Out? Cambridge University Press Melbourne p 211.

${ }^{8}$ Whiteford Peter 'Understanding poverty and social exclusion' 2001 R Fincher and P Saunders above note 3; Bell Stephen The unemployment crisis and economic policy' 2000 above note 7.

${ }^{9}$ Bell above note 7 .
} 
... the health of the economy is everything. All other policy goals must be subordinated to the interests of the economy; government action and regulation is bad; the market is the best mechanism for allocating resources, goods and services; the profit-making sector should be given pride of place through programmes of privatisation $^{10}$.

From the realms of government and business, neo-classical economics has penetrated the local, everyday, context so that our lived experiences are created and re-produced through the discourses and language of de-skilling, downsizing, restructuring, outsourcing and privatisation. As Giddens so aptly comments, 'every business guru talks about it and no political speech is complete without it'.11

\subsection{Feminist Challenges to Neo-Classical Economics}

Despite its seeming popularity, there are, of course, critics of this neoclassical economic framework. Feminist economists in particular have offered a range of alternative (nonneoclassical) perspectives on the theory and consequences of supply side policies ${ }^{12}$. Although feminist economic discourses vary in their epistemological framings, they are united in their commitment to subverting the sexual bias inherent in neoclassical economics. A bias which Pru Goward (previous Executive Director for the Office of Status of Women), ardently denies;

the intense competition of post industrialism pays little attention to gender. Thank Goodness. Like Justice, global economics is blind and works best when it is non-discriminatory ${ }^{13}$.

Implicit in the feminist agenda is a concerted effort to promote the role of women in the economy; to disrupt the traditional dichotomy between the public and private spheres ${ }^{14}$; to subvert

\footnotetext{
${ }^{10}$ Ife Jim Rethinking Social Work Longman South Melbourne 1995 at 2.

${ }^{11}$ Giddens Anthony The Third Way The Renew of Social Democracy Polity Press Massachusetts 1999.

${ }^{12}$ Berik, Gunseli ‘Globalization' 1999 J. Peterson and M. Lewis Feminist Economics Edward Elgar London $\mathrm{p} 402$.

${ }^{13}$ Pocock above note 2 at 582 .
} 
the continued gendering of employment ${ }^{15}$; and to challenge the gendered provision of welfare support $^{16}$.

According to Gillian Hewitson ${ }^{17}$, a feminist economist, central to feminists' challenge to neoclassical economics is the privileging of the male as the archetypal rational economic individual. Not only does this blatant sexism discount the paid and unpaid work undertaken by women but as another feminist economist Randy Arbelda asserts, its inherent masculine bias serves to reinforce the continuing dominance of patriarchal discourses in the current $\operatorname{era}^{18}$. By way of example, whilst neoclassical economics promotes behaviours such as ambition and career-motivation as not only highly desirable characteristics, but consistent with the rational individuals' drive to create 'income and utility maximisation', these traits when enacted by women and men are viewed differently. Women who are 'career-motivated' and ambitious are often constructed as 'pushy', 'cold' and aggressive; her sexuality and femininity in dispute ${ }^{19}$. The same traits, when exhibited by men, are considered to be in keeping with his natural role as provider and protector of the passive female and as such bolster his 'essentialised' masculinity ${ }^{20}$. This example not only rebukes neo-classical economics' depiction of the abstract 'un-gendered' rational individual but considering its position as a central tenet of the economic discourse calls into question the entire neoclassical economic tradition.

\section{LABOUR MARKET DEREGULATION \& THE LAW}

Throughout most of the twentieth century in Australia, protectionism played a critical role in shaping the nature and form of employment regulation including wage determination. Whilst protectionism had often been the cause of raging political debate between the right and the left, between workers, unions and business, it wasn't until the mid 1980s and the economic policies of the Hawke-Labour Government that protectionism's dominance began to dwindle.

\footnotetext{
${ }^{14}$ Hewitson Gillian Feminist Economics: Interrogating the Masculinity of Rational Economic Man Edgar Elgar London 1999.

15 Lewis Margaret and McGoldrik KimMarie 'Moving Beyond the Masculine Neoclassical Classroom' 2001 Feminist Economics 72 p 91.

${ }^{16}$ Baker Maureen and Tippin David Poverty, Social Assistance and the Employability of Mothers: Restructuring Welfare States University of Toronto Press Toronto.

${ }^{17}$ Hewitson above note 14.

${ }^{18}$ Arbelda Randy Economics and Feminism: Disturbances in the Field Twayne Publishers New York 1997.

${ }^{19}$ Smith Dorothy Texts Facts and Femininity: Exploring the relations of Ruling Routledge London 1990 at 182.

${ }^{20}$ Hewitson above note 14 .
} 
The corporatist model of government adopted by Bob Hawke (Prime Minister 1983-1990) and later expanded by Paul Keating (Prime Minister 1990-1996) acted as a catalyst for key employer organisations, such as the Business Council of Australia (BCA), seeking to change the ways labour was regulated. Consistent with neoclassical economic perspectives on the operation of labour markets, the BCA argued that prevailing forms of labour regulation were highly 'paternalistic' and that the uninvited third party intervention placed unnecessary constraints on the development of a work culture based upon flexibility and choice ${ }^{21}$. The BCA lobbying was finally rewarded when in 1991, the Australian Industrial Relations Commission (AIRC) begrudgingly adopted the 'Enterprise Bargaining Principle' (EBP) ${ }^{22}$. Under this principle workers could only gain access to wage adjustments through negotiations within an enterprise agreement.

Over the course of the 1990s a number of legislative amendments were pursued at state and federal levels to support and encourage enterprise bargaining. In 1993 the Industrial Relations $\underline{\text { Reform Act }}$ was also introduced and, with it, the institutionalisation of an award safety net for workers unable to bargaining or reach agreement in the workplace. A mechanism which had become a necessity given the vast number of low paid workers unable to negotiate a wage increase since the introduction of the EBP in 1991.

The nature and forms of legislative amendments introduced in support of labour market deregulation were implicitly linked with politics. Victoria (in 1992) and Western Australia (in 1993) were amongst the first states to introduce radical legislative reform following the election of Liberal governments. At the federal level, not surprisingly, one of the first acts of the Howard Liberal-National coalition government, in March 1996, was the development of new federal industrial relations legislation; the Workplace Relations and Other Legislation Amendment Act 1996 (WROLA). Whilst the WROLA marked a watershed in the regulation of Australian labour markets it was also another feather in John Howard's 'neo-liberal' cap, as he describes;

Of all the issues I have been committed to over the last ten years, none has been more important, none has been more prominent than my absolute commitment to

\footnotetext{
${ }^{21}$ Mclaughlin Peter 'Enterprise Bargaining: Making Australia Competitive' 1990 Economic and Labour Relations Review 1.

${ }^{22}$ Dabscheck Braham 'Stolen entitlements: The 1997 Living Wage Case' Economics and Labour Relations Review 81 p 129.
} 
the need to free Australia's industrial relations system, to change our labour market practices ${ }^{23}$.

Key elements of the WROLA included: provision for direct (employer-employee) non-union agreement making; simplification of awards to twenty 'allowable matters'; conversion of paid rates in awards to a minimum rates structure; relegation of the award structure to a set of 'safetynet' provisions; restrictions on unions on rights of entry and agreement making; and provisions limiting access to redress for unfair dismissal.

\subsection{Labour Reform - Welfare Reform}

The radical changes to industrial relations and the implementation of labour market deregulation were accompanied by a series of welfare reforms which, using the language of neoclassical economics, are designed to create 'incentives' for individuals to find work; to keep in line with the governments 'disciplined approach to fiscal policy"24; and to purge what neo-liberals considered was a 'moral hazard', the culture of welfare dependency; '[although] we can't stop people from needing the dole, we can make it impossible to be idle for long at taxpayers expense $^{, 25}$.

Underpinned by this conservative ethos, the Coalition Government undertook the re-vamping of the previous Labor Government's principles of mutual obligation and 'Work For The Dole' Schemes through the Social Security Legislation Amendment (Work For the Dole) Act 1997. Although employing the language of 'equity' and 'fairness', mutual obligation was the embodiment of the neo-classical and neo-liberal rhetoric of self-sufficiency and self-reliance; a means of shifting 'the culture of welfare to the culture of work...(a) move away from the politics of entitlement into the politics of responsibility,26. According to government rhetoric, it was 'only fair' that tax payers' money was given to those who were 'deserving' and that the tax paying community be given something in return for their support ${ }^{27}$. Through the implementation

\footnotetext{
${ }^{23}$ Rundle Guy 'The opportunist: John Howard and the triumph of reaction' 20013 Quarterly Essay 1 at 33

${ }^{24}$ Commonwealth Department of Family and Community Services 'Part 3 Consolidated Recommendations' Participation Support for a More Equitable Society - Final Report of the Reference Group on Welfare Reform August 2000 at D12.

${ }^{25}$ A comment made by the then Minister for Employment Services, Tony Abbott as cited in Smith Wayne 'The squeeze is on' The Courier-Mail (Brisbane) 10 July 1999.

${ }^{26}$ Smith above note.

${ }^{27}$ Rodgers Kate and Wilson Karen 'Rights and obligations of families in the social security system' Paper presented at Changing families, Challenging futures 6th Australian Institute of Family Studies Conference Melbourne 25-27 November.
} 
of revised schemes such as 'Work For The Dole' (1997) recipients of income support were subject to rigid penalty-based incentives and severe compliance mechanisms.

Such reforms, whilst representing a shift to what the Australian Council Of Social Services (ACOSS) refers to as the 'dead-end approach, at the opposite end of the spectrum to the positive pathways provided by genuine mutual obligation mechanisms ${ }^{28}$, also represent a shift which further compounds the discrimination of women within neo-liberalism. In particular, the compulsory requirement 'to do work (any kind of work) for no pay, simply in return for subsistence-level benefits ${ }^{29}$ not only undervalues the unpaid undertaken by many unemployed and employed women but does little to improve women's access to better jobs through skill-based training, education and experience.

Similarly, women as sole parents, constituting the greatest 'moral hazard' known to neoconservatives, became particular targets of the Government's stringent welfare policies. Whilst married women who stayed at home to care for children were 'rewarded' through a number of tax breaks / incentives (although highly tokenistic), mutual obligation policy stipulated that women as sole parents, who rely upon social security for income must either enter / re-enter the labour market or engage in re-training when their child reaches thirteen years, although the age of six years has also been proposed. ${ }^{30}$

While the policy of mutual obligation garners considerable political capital at the expense of recipients who are portrayed as 'idle', 'irresponsible', 'dependent', 'dole bludgers' and 'welfare cheats $^{31}$, it also hides the realities of globalisation and labour market deregulation. The unemployment problem, for example, is more complex than simply one of supply. What of the demand side when labour markets consistently fail to produce new jobs, particularly new fulltime jobs, the current Government's macroeconomic policy is more concerned with the problem of inflation than job creation? ${ }^{32}$ Viewed from this critical perspective, the economic and social costs of globalisation, labour market deregulation and social security reform are not only deplorable but inhumane.

\footnotetext{
${ }^{28}$ Australian Council of Social Services (ACOSS) Jobs Pack: An Information and Policy Paper ACOSS: Sydney 1998 at 5 .

${ }^{29}$ As above at 5 .

${ }^{30}$ Commonwealth Department of Family and Community Services above note 24 .

${ }^{31}$ Putnis Peter 'Popular discourses and images of poverty and welfare in the news media' 2001 R Fincher and P Saunders above note 3 p 70; Smith above note 25.

${ }^{32}$ Bell above note 7.
} 


\section{COSTS AND CONSEQUENCES OF LABOUR MARKET DEREGULATION}

Since the early 1990s, despite the plethora of women's local stories of the costs and consequences of labour market reforms, gender analysis within public policy has slipped out of view. Forced off the social, economic and political agenda along with the enforced retreat of feminism in bureaucracy and the promulgation of claims that labour market reform has washed away women's disadvantage ${ }^{33}$. However, as any gendered analysis of the labour market demonstrates the reforms implemented over the 1990s have not been gender neutral. As reflected in participation rates, wages and employment characteristics (i.e. forms and conditions of employment), women have borne the brunt of this supposedly un-gendered process. Senator Natasha Stott Despoja asserted her support for the necessity of a continuing feminist agenda in the policy arena by claiming;

To believe that women's rights are not somehow under threat or that we have achieved some ideal situation or equality, especially for women in the workplace today, is very naive at best; it is contemptible at worst. ${ }^{34}$

\subsection{Participation and Employment}

Over the decade to 2001 female participation in the labour market (measured as the proportion of women employed and unemployed as a share of the total female working age population) increased by 3.5 percentage points to 55.4 per cent $^{35}$. (In contrast, male participation rates fell from 74.4 per cent to 72.3 per cent.) Observed trends in participation rates were driven by employment opportunities which, over the decade to 2001 saw the number of women in employment increase by 2.9 per cent - double the recorded growth rate for men (equal to 1.4 per cent). Job growth was particularly concentrated in the part-time labour market, such that by 2001 , 44 per cent of all women were employed in a part-time capacity (holding 72 per cent of all parttime jobs); the balance (56 per cent) were employed full-time ${ }^{36}$. Men, on the other hand, continued to be predominantly concentrated in full-time work ( 87 per cent), with only 13 per cent employed in a part-time capacity. Employers' desire for greater flexibility in relation to

\footnotetext{
${ }^{33}$ Pocock above note 2 at 50 .

${ }^{34}$ Stott Despoja Natasha Available http://www.democrats.org.au/people/stottdespoja/womenpower.html

${ }^{35}$ Australian Bureau of Statistics Labour Force Australia January 2002 Catalogue number 6203.0 Australian Bureau of Statistics Canberra.

${ }^{36}$ Australian Bureau of Statistics Labour Force Australia Preliminary 2002 Catalogue number 6202.0 Australian Bureau of Statistics Canberra.
} 
employment arrangements and the consequent reduction in labour costs, has, as indicated, seen a significant growth in part-time employment, most of it of a casual nature. Casual jobs now account for 27 per cent of all jobs with women holding the majority (54 per cent) of these casual jobs $^{37}$.

\subsection{Unemployment and Hidden Unemployment}

The flexibility demanded by employers and industries within a competitive market place means that full employment is a relatively obsolete phenomenon and unemployment is now a taken for granted reality within a capitalist context ${ }^{38}$. As such, the favourable employment growth rates noted above must be read in conjunction with available statistics on unemployment and hidden employment. The official unemployment rate (which measures the proportion of individuals wishing to work, available to work and actively looking for work, as a proportion of the total labour force (employed plus unemployed)) is currently around 7.1 per cent for women and 7.6 for men $^{39}$.

Table 1: Unemployment Rates, January 2002

\begin{tabular}{|l|l|l|l|}
\hline & $\begin{array}{l}\text { Looking for Full-Time } \\
\text { Work }\end{array}$ & $\begin{array}{l}\text { Looking for Part-Time } \\
\text { Work }\end{array}$ & $\begin{array}{l}\text { Total (full-time plus } \\
\text { part-time) }\end{array}$ \\
\hline Women & $8.5 \%$ & $5.2 \%$ & $7.1 \%$ \\
\hline Men & $7.4 \%$ & $9.1 \%$ & $7.6 \%$ \\
\hline
\end{tabular}

Source: ABS 6203.

However, it must be noted that official unemployment statistics, significantly under-estimate 'true' or 'real' levels of unemployment, particularly amongst women ${ }^{40}$. This under-estimation is referred to as 'hidden unemployment ${ }^{41}$, a phenomenon of unemployment, which for women, is

\footnotetext{
${ }^{37}$ Preston Alison 'The changing Australian labour market: Developments during the last decade' 2001 Australian Bulletin of Labour 273 p 153.

${ }^{38}$ Horin Adele 'Welfare the growth area for women's incomes' Sydney Morning Herald 1 August 2001.

${ }^{39}$ Australian Bureau of Statistics above note at 33.

${ }^{40}$ Watts Martin 2000 'Dimensions and costs of unemployment' S Bell Ed The Unemployment Crisis in Australia: Which Way Out? Cambridge University Press Cambridge 21.

${ }^{41}$ The ABS now refers to hidden unemployment as a generic category of labour under-utilisation. The category encompasses: people whose labour is under-utilised - people who work are willing to work more hours if a position became available and people who are under-employed such that their skills and productive ability are not being fully utilised in their current employment); people who are no longer actively seeking work, due to feelings of discouragement and/or a lack of positions with suitable hours; and those with marginal workforce attachment, such as students and caregivers, whose other commitments may not allow for work outside the home / educational institution for a period of time - Trewin Denis Measures
} 
estimated as constituting approximately 36 per cent of total female unemployment (the corresponding rate for men is 16 per cent $)^{42}$. Hidden unemployment encompasses women who want work, are available to work, but have given up looking for work and are therefore no longer officially considered as part of the labour force.

The issue of women's hidden unemployment is also related to the recent welfare reforms and in particular, reductions in the provision of social security. The dominant policy discourse of mutual obligation and the work for the dole scheme may encourage women to register as undertaking unpaid work and hence, counted as 'not actively looking for work' rather than register as unemployed and be subjected to a system of coerced labour. However, in 'choosing' to remain at home rather than participate in some form of labour market activity or register as unemployed, such women remain relatively invisible; subsumed by the label of hidden unemployment and the repercussions that such a position ensues.

Furthermore, whilst women and men should be provided with the opportunity of working within the home and assuming the role of primary carer to children or another 'dependent' person, such a decision can be problematic in terms of later employment choices and options. As research has found, the human capital accumulated by a woman who 'devotes time and energy to unpaid 'family-specific' activities... is less transportable than that of a partner who specialises in market work ${ }^{43}$. Given this predicament, a woman is confronted by a number of unequal choices; to be placed within a work environment or job which has little social and/or personal meaning or remain at home in a position which remains culturally and socially undervalued and economically un-remunerated ${ }^{44}$.

\subsection{Pay Setting Arrangements \& Earnings}

Differing trends in part-time and full-time employment growth over the last decade must also be read against information on pay setting arrangements. As is evident from Table 2, labour market reforms enacted during the 1990s have delivered a bi-furcated wages system in which the majority of workers remain highly dependent on the award system (23.2 per cent are solely dependent on the Award, while a further 38.2 per cent have an informal pay setting arrangement

of Under-Utilised Labour - Information Paper Australian Bureau of Statistics Canberra; Preston above noted 38 at 163).

${ }^{42}$ Preston above note 37 at 161.

${ }^{43}$ Badgett M V and Folbre Nancy 'Assigning care: Gender norms and economic outcomes', International Labour Review 1383 p 311.

${ }^{44}$ As above. 
that may involve above the Award negotiations). Only 37 per cent of the total workforce set their pay via enterprise negotiations ${ }^{45}$.

Table 2: Methods of Setting Pay (\% employees), May 2000

\begin{tabular}{|c|c|c|c|c|}
\hline & Awards only & $\begin{array}{l}\text { Collective } \\
\text { Agreements }^{(a)}\end{array}$ & $\begin{array}{l}\text { Informal } \\
\text { Agreements }^{(\mathrm{b})}\end{array}$ & Total \\
\hline \multicolumn{5}{|l|}{ Males } \\
\hline Full-time employees & 12.4 & 37.5 & 50.1 & 100.0 \\
\hline Part-time employees & 37.4 & 33.3 & 29.3 & 100.0 \\
\hline All employees & 16.8 & 36.7 & 46.5 & 100.0 \\
\hline \multicolumn{5}{|l|}{ Female } \\
\hline Full-time employees & 19.9 & 38.3 & 41.8 & 100.0 \\
\hline Part-time employees & 40.8 & 35.1 & 24.1 & 100.0 \\
\hline All employees & 29.9 & 36.8 & 33.3 & 100.0 \\
\hline
\end{tabular}

Women, and part-time workers in particular, are more likely than other labour market group to be covered by an Award and, thus, affected by decisions of industrial tribunals and courts in relation to adjustments in the rates of pay specified within the Award. The significance of this, as it relates to a discussion on earnings, is that wage increases within the Award stream (around 1.5 per cent per annum) have been deliberately constrained to be below those in the bargaining stream (around four per cent per annum) as a way of enticing workers to engage in enterprise bargaining. The gender-biased nature of this 'incentive' system is blatently obvious. The firms in which women tend to be employed (eg. small firms) either do not have the infrastructure required to conduct enterprise bargaining or, more importantly, the interest in doing so. Enterprise bargaining tends to be favoured by larger firms and workers employed under full-time contracts, which in the Australian labour market is equal to once again favouring men. For women who do have access to the enterprise bargaining process, issues relating to the attainment of specific knowledge and power become problematic. In order to effectively negotiate enterprise agreements, women as workers require the type of 'insider knowledge' upon which such agreements are based; knowledge of industrial relations, particularly in relation to employee rights and employer

\footnotetext{
${ }^{45}$ Australian Bureau of Statistics Employee Earnings and Hours Catalogue Number 6306 Australian Bureau of Statistics Canberra 2001.
} 
responsibilities, such as casual loadings, leave entitlements and earning rates ${ }^{46}$. Furthermore, as women's access to education, workplace training and union representation is relatively low, women are placed in a relatively vulnerable or exposed position within the gendered power plays which infuse many employer - employee relations ${ }^{47}$.

Notwithstanding developments with respect to pay setting arrangements, the ratio of female to male full-time earnings has remained relatively constant over the 1990s at around 88.5 per cent $(\text { see Table } 3)^{48}$. Despite this apparent positivism Gillian Whitehouse argues that the "relatively benign impression from the aggregate gender pay ration statistics have a more problematic side $^{49}$. For instance, for women employed part-time, when benchmarked against full-time employees it is apparent that they have suffered a significant deterioration in their relative earnings over the decade; against men employed full-time the gap has grown by 7 percentage points, the corresponding change for women employed part-time relative to women employed full-time is 9.5 percentage points. These statistics support the argument that enterprise bargaining and its associated fragmentation of prevailing pay setting arrangements have adversely impacted on women.

Table 3: Total (ordinary plus overtime) Average Hourly Earnings Ratios, 1991 and 2000

\begin{tabular}{|l|l|l|l|}
\hline & 1991 & 2000 & \% point change \\
\hline F-ft/M-ft & 88.5 & 88.6 & 0.1 \\
\hline F-pt/M-ft & 88.3 & 81.3 & -7.0 \\
\hline F-pt/F-ft & 99.7 & 90.2 & -9.5 \\
\hline
\end{tabular}

Source: ABS 6306.

Women's predominance in part-time and casual positions, which attract low extrinsic and intrinsic rewards, is also problematic in terms of their access to government-provided income support. The tightening of the social security agenda instigated through the Government's welfare reform agenda and specifically, its regeneration of mutual obligation, have in effect, limited

\footnotetext{
${ }^{46}$ Strachan Glenda and Burgess John 'The incompatibility of decentralized bargaining and equal employment opportunity in Australia' 2000 British Journal of Industrial Relations 383361.

${ }^{47}$ Wajcman Judy 'Feminism facing industrial relations in Britain' 2000 British Journal of Industrial Relations 382183 at 187.

${ }^{48}$ ABS above note 43.

${ }^{49}$ Whitehouse Gillian 'Recent trends in pay equity: Beyond the aggregate statistics' 2001 Journal of Industrial Relations 43166 at 69.
} 
women's decisions to work or not work to issues of economic and financial viability. For many women who work casually / part-time, the economic stress and financial insecurity accompanying flexible employment means that income support is a necessity ${ }^{50}$.

Yet, the penalty of a high effective marginal tax rate on the first dollar earned above the stipulated threshold, applied to a recipient's and/or their (male) partner's earnings are such that allowances are reduced or cancelled if earnings in any fortnight exceed the social security threshold. ${ }^{51}$ Without such income support it is relatively impossible for many of these women to maintain a reasonable standard of living, let alone plan for financial independence or provide a future for their child/ren. This alongside the rising costs of formal childcare; travel; market substitutions for women's domestic labour ${ }^{52}$; and the significant rise in living costs, means that the net income earned by a woman is either exceeded or significantly reduced ${ }^{53}$.

Given the low rates of earnings, as illustrated in the above figures, participation in the labour market for many women is only financially viable if remuneration is that of the full-time wage and yet it is full-time employment is the most difficult for women to secure. The singular focus on financial viability in women's decisions of work, has a number of other repercussions; economics may override the social and emotional benefits derived from employment; it may 'force' women into using unsupervised, informal childcare; and/or discourage women who earn low or middle incomes, from pursuing paid work. ${ }^{54}$ In all such instances the costs of work may indeed outweigh any financial benefit. ${ }^{55}$.

\footnotetext{
${ }^{50}$ Women's Electoral Lobby (WEL) WEL National Policies December 2000 Part 1 Women's Electoral Lobby Canberra Available Online http://www.wel.org.au/policy/00poll.htm.

${ }^{51}$ Commonwealth Department of Family and Community Services above note 27.

${ }^{52}$ Bittman Michael 'Parenting without penalty: Time use and public policy in Australia and Finland' Feminist Economics 5327.

${ }^{53}$ Women's Electoral Lobby (WEL) Constructing a $21^{\text {st }}$ Century Social Support System: 2 Women's Electoral Lobby Canberra 1999 Available Online http://www.wel.org.au/issues/welfare/welfare2.htm.

${ }_{55}^{54}$ Women's Electoral Lobby above note 51.

${ }^{55}$ As above.
} 


\subsection{Employment Characteristics - Job Quality}

As a result of labour market reforms and enterprise bargaining, patterns of labour use, such as the forms and hours of employment, have significantly altered. As has previously been established, the increased emphasis on competition alongside the primacy of the market in determining supply and demand has led to the increased use of casual labour. Whilst the flexibility of casual / parttime work arrangements can provide women with increased work opportunities and a better way of managing (sic) the work / family balance, Gillian Pascal reminds us that 'freeing up the labour market is intended to enhance the profits of capital rather than to liberate women'. ${ }^{56}$

If part-time work were accorded similar status and conditions to that of full-time work these trends would not be disconcerting. However, there are significant differences in job quality, status, opportunities and earnings. Part-time jobs, for example, are more likely than full-time jobs to be casual and hence, devoid of entitlements with respect to leave and holiday pay and tenuous with respect to security ${ }^{57}$. Part-time jobs are also less likely to be covered by an enterprise agreement, leaving workers, the majority of whom are women, dependent on the AIRC Living Wage Case rulings which prescribe a safety-net or minimum adjustment process to wage determination. Part-time jobs (an in particular part-time casual jobs) are also more likely to be marginal to other workplace processes such as training, communication and promotion as has been noted by Barbara Pocock, who asserts, 'such workers are peripheral in the minds of managers and 'proper' workers alike ${ }^{58}$.

The low rates of pay, the unsociable hours of work, alongside the lack of worker entitlements means that for many women in casual or part-time employment access to social security allowances are a financial necessity. Yet, with the government's seemingly insatiable drive to rid itself of this public responsibility, access to such monies is becoming increasingly difficult. In conjunction with the restrictions, the Coalition Government has stepped up its program of surveillance, as developed in their policy of profiling and data matching; programs aimed at exposing welfare cheats. Recently, this profiling has identified the archetypal 'welfare cheat' as

\footnotetext{
${ }^{56}$ Pascall Gillian 'Family, work and state' 1997 Social Policy: A New Feminist Analysis Routledge London p 30 at 71.

${ }^{57}$ Preston above note 35; Strachan and Burgess above note 44.

${ }^{58}$ Pocock above note 2 at 537.
} 
one who receives irregular income and works unpredictable hours ${ }^{59}$. Such a description depicts the causal worker and thus, the women who hold the majority of casual positions.

Whilst disputing the accusation of the casual worker / women as the typical welfare cheat, this finding, comes as no surprise considering that the absence of a regular and predictable income from employment (a feature of casual jobs) necessitates additional income generating/income support arrangement, such as that provided through social security allowances. As a result of this latest expose, a greater number of casuals and as such women will be forced under the 'welfare spotlight' and subject to yet further government investigation. Considering the stress which many women as casual workers experience, given the insecurity of income, low pay, poor quality job and tenuity of employment, the threat of investigation for some women will make the 'choice' clear; the 'costs' and stresses of employment will outweigh any 'benefits' derived from such work. As a result many women will either return to unpaid work and the ranks of hidden unemployment or become reliant on the social security system with its harsh penalties and unrealistic expectations.

The quality of women's employment is also related to the type of agreement or award she is covered by and the 'privileges' that the form of wage determination provides employers. For instance, individual contracts have been used by employers to enhance their own position; to assert managerial prerogative; deliver 'managerial flexibility' ${ }^{60}$; to systematically deregulate working time arrangements through the extension of the 'normal' working day, averaging hours and extending shifts ${ }^{61}$; and to increase the use of 'out sourcing' or 'contracting out ${ }^{\text {' }}$. Whilst the expansion of the 'working day' has occurred across the labour market, it has been (and continues to be) widespread in sectors where women are predominant; sectors such as financial services, wholesale/retail trade and recreational services ${ }^{63}$. In general, women as workers in these sectors are employed in casual and part-time positions and hence, have limited control over their working

\footnotetext{
${ }^{59}$ Sydney Morning Herald Welfare Blitz Fits Cheats to Profile 16 January 2001

${ }^{60}$ Australian Centre for Industrial Relations Research and Training (ACIRRT) Australia at Work: Just Managing? Prentice Hall Sydney 1999.

${ }^{61}$ Watts Martin and Burgess John 'The polarisation of earnings and hours in Australia under a decentralised industrial relations system: Lessons for economic policy' 2000 International Journal of Employment Studies 8127.

${ }^{62}$ Watson Ian and Buchanan John 'Beyond impoverished visions of the labour market', in Fincher and Saunders above note 3194 at $198-199$.

${ }^{63}$ Lee Julie and Strachan Glenda 'Family preferences, child care and working hours' 1999 Journal of Australian Political Economy 4322.
} 
conditions, the pace of work and wages. ${ }^{64}$ The quality of such jobs is also affected by the lack of protection offered through legislation, particularly with respect to unfair dismissal laws; the relative safety of collective agreements; and access to non-wage benefits such as holiday and sick leave, salary sacrificing / packaging provisions and superannuation contributions above the mandated minimum. ${ }^{65}$

The issue of the extended working day has a number of implications for women. Figures accounting for the number of hours women and men work per day show, that on average, women's total work time exceeds that of men ${ }^{66}$. Whilst women and men spend a similar number of hours per day in paid employment, the difference in the total hours per day worked, relates to the extra hours undertaken by women in unpaid work or what Badgett and Folbre refer to as 'family-specific activities ${ }^{67}$. The consequences for women of the longer working day / night whilst increasing the costs of childcare and other associated expenditure, have been reported as once again compounding the stress which many women already experience in their 'double/treble burden of care ${ }^{98}$. As calculations show, on average, women spend 57 per cent more time involved in domestic activities than their male counterparts ${ }^{69}$. Such data further indicates that despite changes to traditional framings of gender, deregulation has done nothing to remove the essentialist notions of femininity and masculinity or the prescriptive and descriptive stories of women as responsible for family and domestic work which remain firmly entrenched in many cultures $^{70}$.

\footnotetext{
${ }^{64}$ Burgess John and de Ruyter Alex 'Declining job quality in Australia: Another hidden cost of unemployment' J Burgess and G Strachan Eds Research on Work, Employment and Industrial Relations 2000 Proceedings of the $14^{\text {th }}$ AIRAANZ Conference University of Newcastle Newcastle (NSW) 1.

${ }^{65}$ Strachan and Burgess above note 45.

${ }^{66}$ Australian Bureau of Statistics How Australian's Use Their Time1997 Catalogue number 4153.0 Australian Bureau of Statistics Canberra.

${ }^{67}$ Badgett and Folbre above note 45 at 311.

${ }^{68}$ ACIRRT above note 60.

${ }^{69}$ Australian Bureau of Statistics Catalogue above note 66.

${ }^{70}$ Austen Siobhan and Birch Elisa Family Responsibilities and Women's Working Lives 2000 Discussion Paper 00/3 Available http://www.cbs.curtin.edu.au/Workingpapers/WEPAU/00-3.pdf; Badgett and Folbre above note 45 .
} 


\section{SUMMARY AND CONCLUSION}

Since the early 1990s, Australia has seen a growing integration of national economies and an increasing public acceptance of the neo-liberal economic agenda with respect to product deregulation, labour market reform, tariff reduction, privatisation and the dismantling of the welfare-state. At the political level the neo-liberal rhetoric suggests that these reforms will deliver improved living standards and choice for all Australians. Whilst certain groups, such as 'high paid' workers have clearly benefited from the reforms, low income earners have experienced a deterioration in their relative pay ratio such that rising wage inequality is a taken-for-granted feature of the Australian labour market.

Whilst the Howard Government continues to champion the benefits of labour market reform and mutual obligation in separating the 'workers' from the 'bludgers' and the 'deserving' from the 'undeserving', many Australian women sink further into a quagmire of social, economic and political disadvantage. Such an appalling state of play after nearly six years in Government, within an economy that continues to grow despite recessions elsewhere, illustrates not only the governments inadequacy and ineptitude in dealing with socio-economic issues but points to governments failure to keep up with the changing needs, wants and expectations of women and their families in the $21^{\text {st }}$ century. What is missing in the Government's reform agendas apart from a genuine concern for the many Australians striving to cope with meeting their needs in a highly transitory economic context, is an authentic commitment to creating a culture which is not only supportive of women but an environment which offers women 'choices'.

In conclusion, it is hoped that this feminist critique of the patriarchal, neo-classical, economic model guiding globalisation, labour market deregulation and welfare reform exposes the complexities of women's lives and the gender biased laws enacted in support of this economic framework. Whether lawyers or economics, feminists or pro-feminists, we have a role in maintaining such critiques until such time as women are able to make 'real' social, economic and political choices. 


\section{REFERENCES}

Arbelda Randy Economics and Feminism: Disturbances in the Field Twayne Publishers New York 1997.

Austen Siobhan and Birch Elisa Family Responsibilities and Women's Working Lives 2000 Discussion

Paper 00/3 Available http://www.cbs.curtin.edu.au/Workingpapers/WEPAU/00-3.pdf.

Australian Bureau of Statistics Employee Earnings and Hours 2001 Catalogue Number 6306.0 Australian Bureau of Statistics Canberra .

Australian Bureau of Statistics Labour Force Australia January 2002 Catalogue number 6203.0 Australian Bureau of Statistics Canberra.

Australian Bureau of Statistics Labour Force Australia Preliminary 2002 Catalogue number 6202.0 Australian Bureau of Statistics Canberra.

Australian Centre for Industrial Relations Research and Training (ACIRRT) Australia at Work: Just Managing? Prentice Hall Sydney 1999.

Australian Council of Social Services (ACOSS) Jobs Pack: An Information and Policy Paper ACOSS: Sydney 1998.

Badgett M V and Folbre Nancy 'Assigning care: Gender norms and economic outcomes', International Labour Review 1383 p 311.

Baker Maureen and Tippin David Poverty, Social Assistance and the Employability of Mothers: Restructuring Welfare States University of Toronto Press Toronto

Bell Stephen 'The unemployment crisis and economic policy' $2000 \mathrm{~S}$ Bell Ed The Unemployment Crisis in Australia: Which Way Out? Cambridge University press Melbourne p1

Berik, Gunseli ‘Globalization' 1999 J. Peterson and M. Lewis Feminist Economics Edward Elgar London p 402 
Bittman Michael 'Parenting without penalty: Time use and public policy in Australia and Finland' Feminist Economics 5327

Burgess John and de Ruyter Alex 'Declining job quality in Australia: Another hidden cost of unemployment' J Burgess and G Strachan Eds Research on Work, Employment and Industrial Relations 2000 Proceedings of the $14^{\text {th }}$ AIRAANZ Conference University of Newcastle Newcastle (NSW)

Capling Ann Considine Mark and Crozier Michael Australian Politics in the Global Era Addison Wesley Longman Melbourne 1998

Commonwealth Department of Family and Community Services Participation Support for a More Equitable Society: Final Report of the Reference Group on Welfare Reform Department of Family and Community Services Canberra 2000

Commonwealth of Australia The Workplace Relations and Other Legislation Amendment Act 1996 (Cth) Commonwealth of Australia Canberra

Dabscheck Braham 'Stolen entitlements: The 1997 Living Wage Case' Economics and Labour Relations Review 81 p 129

Fincher Ruth and Saunders Peter Eds 'The complex contexts of inequality in Australia' Creating Unequal Futures? Rethinking Poverty, Inequality and Disadvantage Allen and Unwin Australia p 38

Giddens Anthony The Third Way The Renew of Social Democracy Polity Press Massachusetts 1999

Gordon Michael and Henderson Ian 'Sun's out, make hay, Howard says', The Australian 18 July 1997

Hewitson Gillian Feminist Economics: Interrogating the Masculinity of Rational Economic Man Edgar Elgar London 1999 
Horin Adele 'Welfare the growth area for women's incomes' Sydney Morning Herald 1 August 2001

Ife Jim Rethinking Social Work Longman South Melbourne 1995

Lee Julie and Strachan Glenda 'Family preferences, child care and working hours' 1999 Journal of Australian Political Economy 4322

Lewis Margaret and McGoldrik KimMarie 'Moving Beyond the Masculine Neoclassical Classroom’ 2001 Feminist Economics 72 p 91

Mclaughlin Peter 'Enterprise Bargaining: Making Australia Competitive' 2000 Economic and Labour Relations Review $1 \mathrm{p}$

Mitchell Deborah 'The sustainability of the welfare state: debates, myths, agendas'1997 Just Policy 9 p 53

Pascall Gillian 'Family, work and state' 1997 Social Policy: A New Feminist Analysis Routledge London

Plowman David 'Protecting the low income earner: Minimum wage determination in Australia' 1995 Economics and Labour relations Review 62 p 252

Pocock Barbara 'All change, still gendered: The Australian labour market in the 1990s' The Journal of Industrial Relations 1998404 p 580

Preston Alison 'The changing Australian labour market: Developments during the last decade' Australian Bulletin of Labour 273 p.153

Putnis, Peter, 'Popular discourses and images of poverty and welfare in the news media' $2001 \mathrm{r}$. Fincher and P. Saunders (Ed) Creating Unequal Futures: Rethinking Poverty, Inequality and Disadvantage, Allen \& Unwin, St. Leonards.

Quiggan John 'The public sector as a job engine' 2000 S Bell Ed The Unemployment Crisis in Australia: Which Way Out? Cambridge University Press Melbourne p 211 
Rees Stuart 'Economic rationalism: An ideology of exclusion' 1994 Australian Journal of Social Issues $292 \mathrm{p} 171$

Rodgers Kate and Wilson Karen 'Rights and obligations of families in the social security system' Paper presented at Changing families, Challenging futures 6th Australian Institute of Family

Studies Conference Melbourne 25-27 November

Rundle Guy 'The opportunist: John Howard and the triumph of reaction' 2001 Quarterly Essay 3

Singleton Gwynneth 'Introduction: Howard’s way’ 2000a Ed The Howard Government:

Australian Commonwealth Administration 1996-1998 University of New South Wales Press Sydney

Smith Dorothy Texts Facts and Femininity: Exploring the relations of Ruling Routledge London 1990

Smith Wayne 'The squeeze is on' The Courier-Mail (Brisbane) 10 July 1999

Stott Despoja Natasha Available http://www.democrats.org.au/people/stottdespoja/womenpower.html

Strachan Glenda and Burgess John 'The incompatibility of decentralized bargaining and equal employment opportunity in Australia' 2000 British Journal of Industrial Relations 383361

Sydney Morning Herald Welfare Blitz Fits Cheats to Profile 16 January 2001

Trewin Denis Measures of Under-Utilised Labour - Information Paper Australian Bureau of Statistics Canberra

Wajcman Judy 'Feminism facing industrial relations in Britain' 2000 British Journal of Industrial Relations 382183

Watson Ian and Buchanan John 'Beyond impoverished visions of the labour market' R Fincher and P Saunders Eds Creating Unequal Futures? Rethinking Poverty, Inequality and Disadvantage Allen and Unwin Australia p 194 
Watts Martin and Burgess John 'The polarization of earnings and hours in Australia under a decentralized industrial relations system: Lessons for economic policy' 2000 International Journal of Employment Studies 8127

Watts Martin 'Dimensions and costs of unemployment' 2000 S Bell ed The Unemployment Crisis in Australia: Which Way Out? Cambridge University Press Cambridge p 21

Whiteford Peter 'Understanding poverty and social exclusion' 2001 R Fincher and P Saunders

Eds Creating Unequal Futures? Rethinking Poverty, Inequality and Disadvantage Allen and Unwin Australia p38

Whitehouse Gillian 'Recent trends in pay equity: Beyond the aggregate statistics' 2001 Journal of Industrial Relations 43166

Wiseman John Global Nation? Australia and the Politics of Globalisation Cambridge University Press New York 1998

Women's Electoral Lobby (WEL) Constructing a $21^{\text {st }}$ Century Social Support System: 2 Women's Electoral Lobby Canberra 1999 Available http://www.wel.org.au/issues/welfare/welfare2.htm

Women's Electoral Lobby (WEL) WEL National Policies December 2000 Part 1 Women's Electoral Lobby Canberra Available http://www.wel.org.au/policy/00pol1.htm 